\title{
Businesses as social partners in gender policies: Assessment of the actors' expectations to contribute to gender equality
}

\begin{abstract}
Businesses tend to be the target of policies due to their rare commitment to matters concerning equality, although new governance guidelines in the gender mainstreaming strategy propose more active participation on their part. This study explores the use of AHP in the case of Colombian to understand more about this conflicting scenario and a potential new business role. This research focuses on expectations of businesses committed to corporate social responsibility and expectations of other conventional policy actors (government, equality organizations, and academia) with respect to businesses. The results reveal a possible role shift towards businesses in more active positions and also possible misunderstandings arising from divergent expectations. The AHP was useful for detecting various role gaps in business self-concept and the perception of other actors with regards to potential capabilities contributing to the policies.
\end{abstract}

Keywords: gender policy, corporate social responsibility, businesses, Analytic Hierarchy Process AHP.

\section{Introduction}

Most national and international public policies on equality allude to the great potential of the business sector, especially with regards to women's employment and glass ceiling, but also increasingly in other aspects such as the fight against gender violence or promoting co-responsibility in care. However, gender equality/inequality in the business sector is monitored through various indicators, reflecting a starting point with room for improvement, in many cases worse than in other areas such as the public or associative sectors. Moreover, the actor that has traditionally participated in the policies, the associations that represent the group of firms, has commonly not been inclined towards measures for equality and these are remarkably masculinized organizations, especially in their leadership roles (Casey et al., 2011). This situation has resulted in the predominant focus on the business sector overall as a group of entities in which to raise awareness and as a target of equality policies, and to a lesser extent, it suggests more active and collaborative participation in developing said policies.

Nevertheless, within the corporate social responsibility (CSR) framework we find private firms that are examples of commitment, and sometimes the launching point for innovations in organizational policies on equality. This facet of firms as emerging actors in policy governance has been studied less, and we know very little about how the committed business sector sees its potential global role in equality policies beyond the realization of concrete business practices (Grosser \& McCarthy, 2019). Likewise, we know very little about what other business stakeholders expect of businesses, such as equality organizations or universities, or other actors with a growing presence in the public debate with positions that may be contrary to equality, such as religious organizations. 
Our work explores possible firm's global role shifts towards more involvement in equality policies, as well as possible discrepancies in expectations that the actors have among themselves (role gaps) in their possible contribution to equality polices forums.

Our research is based in Colombia, a country with notable evolution of its equality policies (UN Women, 2018), as well as growing business activity in matters related to corporate social responsibility and equality (Bastidas and del Carmen Briano-Turrent, 2018). In Colombia, the presence of non-state actors in social action is key, given the lower implementation of public social policies, and, overall, the limited scope of public administration in some parts of the country.

Our work allows to observe the role of businesses as possible actors and not only as the target of equality policies. Another contribution of this article is the theoreticalmethodological approach that it allows in order to capture new realities of relationships based on the consideration of the actors involved.

\section{Literature Review}

The research was informed by the following key theoretical proposals:

- Equality policies from univocal views about what equality is and how to achieve it (Bacchi, 2005).

- Equality policies defined as "clusters" of views about how to deal with gender issues (Verloo and Lombardo, 2007).

- Equality/inequality and their narratives manifested in different policies (Bruno, Jacquot, \& Mandin, 2006) (Blackmore, 2011; Jacquot, 2010).

- The use of AHP in private and public participatory processes, as well as in seeking a consensus in regulatory domains (Gómez-Navarro et al., 2009; Peris et al., 2013).

\section{Hypotheses/Objectives}

The main research objective for the present study is to explore the use of AHP in the assessment of expectations between businesses and different types of institutions with respect to potential contributions to gender policies.

We want to explore: a) the view of businesses with respect to their own role and capabilities in new governance contexts to contribute to equality policies more proactively and $b$ ) the view and expectations with respect to the business role by other actors in equality policies in new governance contexts

\section{Research Design/Methodology}

Given the highly exploratory nature of the research, the chosen methodology is qualitative and uses a participatory multi-criteria decision-making method (MCDM), in particular the AHP (Saaty, 2008). The AHP allows us to determine the relative importance of intangible aspects such as related to the capabilities for contributing to policies. The main phases are presented in the next figure: 


\begin{tabular}{|l|l|}
\hline - Identification of related equality policy history in Colombia \\
\hline Pelection of participating actors \\
\hline D & $\begin{array}{l}\text { - Prioritization using a questionnaire created with the options } \\
\text { included in the decision model }\end{array}$ \\
\hline E & - Comparison and analysis of the results \\
\hline
\end{tabular}

\section{Data/Model Analysis}

The prioritization process includes two AHP hierarchies. It was constructed in two different phases: 1) prioritization of the work areas, and 2) prioritization of the potential contributions for the most valued work area.

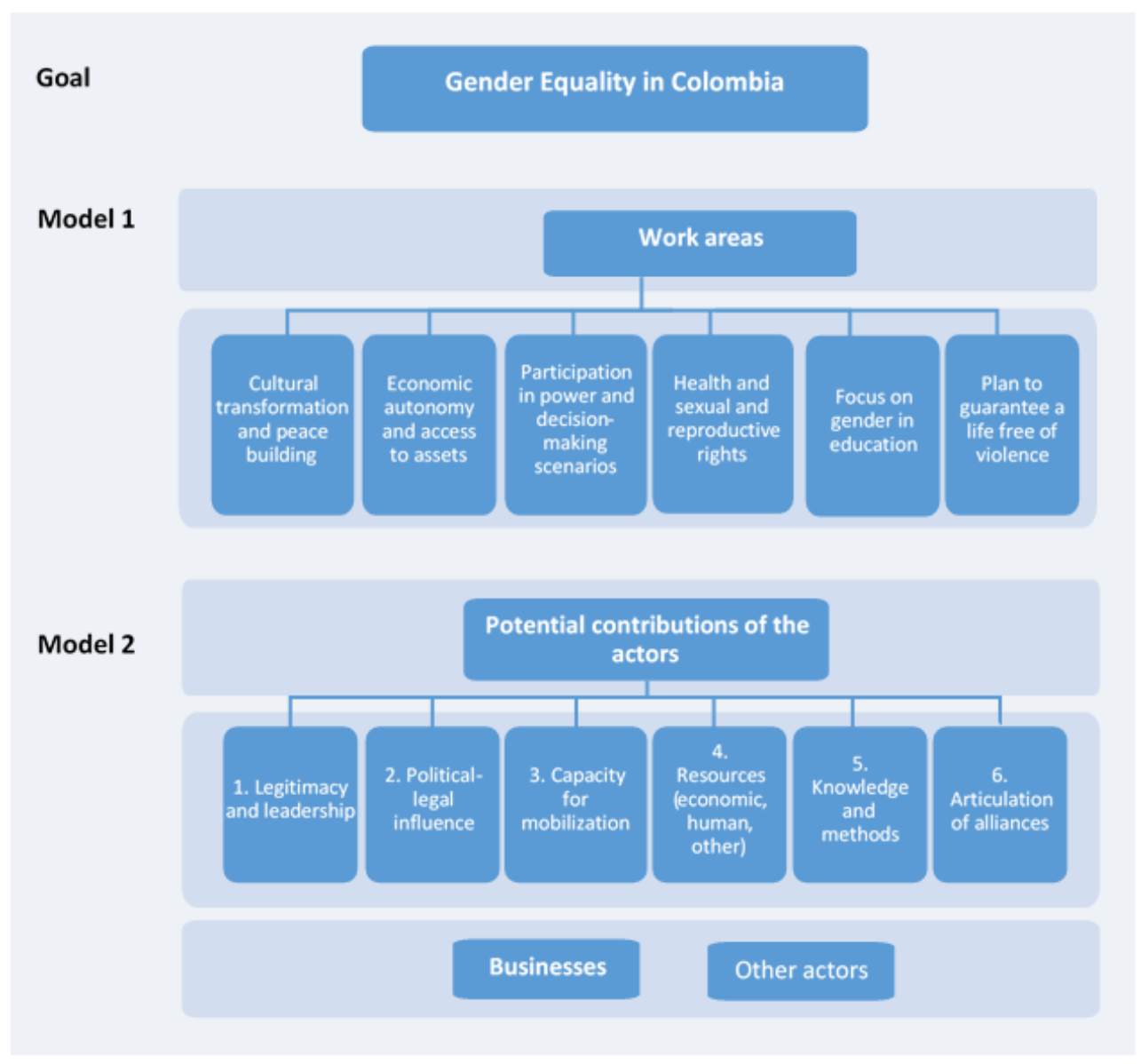


ISAHP Article: A Style Guide for Paper Proposals To Be Submitted to the International Symposium on the Analytic Hierarchy Process 2020, Web Conference.

The first phase of prioritization was selecting one of the work areas on which to specifically evaluate the potential contributions. The questionnaire had questions like the following:

Which of the two work areas do you consider most relevant to advancing gender equality in Colombia? To what extent?

\begin{tabular}{|c|c|c|c|c|c|c|c|c|c|c|}
\hline & 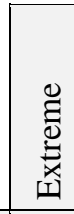 & 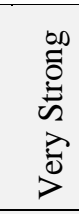 & $\underset{\mathscr{0}}{0}$ & $\frac{0}{\frac{\pi}{\pi}}$ & 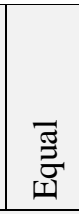 & 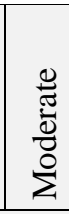 & 告 & 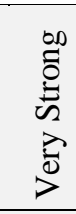 & 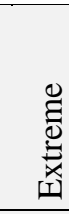 & \\
\hline $\begin{array}{l}\text { 1. Cultural } \\
\text { transformation and } \\
\text { peacebuilding }\end{array}$ & 9 & 7 & 5 & 3 & 1 & 3 & $\mathrm{x}$ & 7 & 9 & $\begin{array}{l}\text { 2. Economic autonomy } \\
\text { and access to assets }\end{array}$ \\
\hline
\end{tabular}

The second phase was developed using two types of questions. In the first type of questions, the same structure of pairwise comparison was used to evaluate the actor's possible contribution to the selected area. In the second type of questions, an intensity scale was used to score each one of the capabilities of the businesses and other participating actors. Given the number of actors considered, the method recommends using this type of question in order to simplify the evaluation and avoid inconsistencies. The questionnaire had questions like the following:

Please rate the different actors according to what they contribute with P1. Legitimacy and Leadership for developing economic autonomy and access to assets

\begin{tabular}{|l|l|l|l|l|l|l|}
\hline & $\begin{array}{l}\text { Not at all } \\
\text { important }\end{array}$ & $\begin{array}{l}\text { Slightly } \\
\text { important }\end{array}$ & $\begin{array}{l}2 \\
\text { Moderately } \\
\text { important }\end{array}$ & $\begin{array}{l}3 \\
\text { Important }\end{array}$ & $\begin{array}{l}4 \\
\text { Very } \\
\text { important }\end{array}$ & \begin{tabular}{l} 
Indispensable \\
\hline Businesses
\end{tabular} \\
\hline$\ldots$ & & & & & & \\
\hline
\end{tabular}

The global results were obtained using the geometric mean (Saaty, 2011).

\section{Limitations}

The proposed approach could be limited in scope; thus, a quantitative approach could confirm or refute the results obtained. Further investigation in other local, regional, and national contexts and in other equality policy issues (education, violence, etc.) would be possible with this framework and would address some of others limitations of this work, focused on the Colombian context and large firms.

\section{Conclusions}

This research empirically captures the potential emergence of a new role for CSR firms in new equality policy governance contexts in Colombia, as well as relevant role gaps or discrepancies in expectations with respect to what actors can contribute to equality policies aimed at improve economic autonomy and access to assets, such as employment policies. It demonstrates that a role shift towards more proactive roles in equality issues is expected 
ISAHP Article: A Style Guide for Paper Proposals To Be Submitted to the International Symposium on the Analytic Hierarchy Process 2020, Web Conference.

by different relevant actors, including businesses themselves - albeit with less intensity on their behalf-reinforcing prior theoretical approaches.

\section{Key References}

List here only those 3 to 5 references that are key for the study at hand. As an example:

Albareda, L., Lozano, J. M., Tencati, A., Midttun, A., \& Perrini, F. (2008). The changing role of governments in corporate social responsibility: Drivers and responses. Business Ethics: A European Review, 17(4), 347-363

Bastidas, C. R., \& del Carmen Briano-Turrent, G. (2018). Las mujeres en posiciones de liderazgo y la sustentabilidad empresarial: Evidencia en empresas cotizadas de Colombia y Chile. Estudios Gerenciales, 385-398.

Gómez-Navarro, T., García-Melón, M., Acuña-Dutra, S., \& Díaz-Martín, D. (2009). An environmental pressure index proposal for urban development planning based on the analytic network process. Environmental Impact Assessment Review, 29(5), 319-329. https://doi.org/10.1016/j.eiar.2008.10.004

Grosser, K., \& McCarthy, L. (2019). Imagining new feminist futures: How feminist social movements contest the neoliberalization of feminism in an increasingly corporatedominated world. Gender, Work \& Organization, 26(8), 1100-1116.

Marcella, G. (2009). Democratic governance and the rule of law: Lessons from Colombia. Strategic Studies Institute.

Peris, J., García-Melón, M., Gómez-Navarro, T., \& Calabuig, C. (2013). Prioritizing Local Agenda 21 Programmes using Analytic Network Process: A Spanish Case Study. Sustainable Development, 21(5), 338-352. https://doi.org/10.1002/sd.514

Saaty, T. L. (2008). Decision making with the analytic hierarchy process. International journal of services sciences, 1(1), 83-98. 